\title{
Polikliniğe Başvuran Hastaların Sağlık Hizmet Algısına Yaşam Kalitesi Ve Sosyodemografik Özelliklerinin Etkisi
}

\author{
The Effect of Quality of Life and Sociodemographic Characteristics of Patients on \\ Health Service Perception
}

\author{
Aylin SARI ${ }^{1}$, Selin SÜSL ̈̈², Özlem AYAZ ${ }^{3}$, Basak BİLİR KAYA ${ }^{1}$
}

\begin{abstract}
1 Deparment of Physical Therapy and Rehabilitation Istanbul Erenkoy Physical Therapy and Rehabilitation Hospital, Istanbul, Turkey

2 Department of Hospital Health Care Services, Istanbul Erenkoy Physical Therapy and Rehabilitation Hospital, Istanbul, Turkey 3 Department of Hospital Health Care Services, Istanbul Erenkoy Physical Therapy and Rehabilitation Hospital, Istanbul, Turkey
\end{abstract}

Özet

Amaç: Bir Fizik Tedavi ve Rehabilitasyon Hastanesinde polikliniğe başvuran hastaların yaşam kalitesi ve sosyo-demografik özelliklerinin sağlık hizmet algısına etkisini belirlemek amacıyla kesitsel olarak planlanmıştır.

Gereç ve Yöntemler: Kesitsel tipteki bu çalışma 15 Haziran- 15 Eylül 2019 tarihleri arası 1 aylık dönemde Fizik Tedavi ve Rehabilitasyon Hastanesi polikliniğine başvuran hastalardan araştırmaya katılma kriterlerini karşılayan ve onam veren ilk 236’sı kadın, 131'i erkek olmak üzere toplam 367 hastada uygulanmıştır. Veriler hastaların sosyo-demografik özellikleri ve memnuniyet düzeylerini ölçen yapılandırılmış form ve hastanın genel algıladığı yaşam kalitesini ölçmek amacıyla geliştirlen Nottingham Sağlık Profili Ölçeği (NSP) kullanılarak toplanmıştır.

Bulgular: Yaş değerleri ile toplam memnuniyet ortalama puanları arasında pozitif yönde istatistiksel olarak anlamlı korelasyon gözlenmiştir $(\mathrm{p}=0,0001)$. Okur-Yazar grubunun toplam memnuniyet ortalama puanları diğer gruplarından istatistiksel olarak anlamlı derecede yüksek bulunmuştur ( $\mathrm{p}=0.032, \mathrm{p}=0.005)$. Hastaneyi Tavsiye Etme $(+)$ grubunun toplam memnuniyet ortalama puanları Hastaneyi Tavsiye Etme (-) grubundan istatistiksel olarak anlamlı derecede yüksek bulunmuştur ( $\mathrm{p}=0,0001$ ). NSP Ağrı ortalama puanları ile toplam memnuniyet ortalama puanları arasında pozitif yönde istatistiksel olarak anlamlı korelasyon gözlenmiştir ( $\mathrm{p}=0.001)$..

Sonuç: Sağlık hizmet algısı hasta-hastane iletişiminde çok farklı faktörlerden etkilenebilir. Yaş, eğitim düzeyi, hastaneyi tavsiye etme durumu ve ağrı varlığı çalışmamızda ilişkili bulduğumuz önemli parametrelerdir. Sunulan hizmetin geliştirilmesinde tüm faktörlerin detaylı bir şekilde incelenip tanımlanması yol gösterici olacaktır.

Anahtar kelimeler: Yaşam kalitesi, sağlık hizmet algısı, memnuniyet

\begin{abstract}
Aim: To determine the effect of quality of life and sociodemographic characteristics of patients admitted to the outpatient clinic of a Physical Therapy and Rehabilitation Hospital on Health Service Perceptions.

Material and Methods: This cross-sectional study was conducted on a total of 367 patients (236 female, 131 male) who met the criteria of participation in the research and applied to the outpatientclinic at a Physical Therapy and Rehabilitation Hospital between June 15 and September 15, 2019. Data were collected using a structured form measuring the socio-demographic characteristics and satisfaction levels of the patient and Nottingham Health Profile Scale (NHP) to measure the general perceived quality of life of the patient.

Results: A statistically significant correlation was found between age values and total satisfaction mean scores $(\mathrm{p}=0.0001)$. Total satisfaction average scores of the literate group were found to be significantly higher than the other groups $(\mathrm{p}=0.032, \mathrm{p}=0.005)$. The total satisfaction mean scores of the Hospital Recommend (+) group were found to be statistically higher than the Hospital Recommend (-) group ( $\mathrm{p}=$ 0.0001). There was a statistically significant correlation between NHP Pain average scores and total satisfaction mean scores $(\mathrm{p}=0.001)$.
\end{abstract}

Conclusion: Health service perception may be affected by many different factors in patient-hospital communication. Age, education, hospital referral status, and presence of pain are essential parameters that we defined in our study. In the development of the health service provided, it will be guided to examine and determine all factors in detail.

Keywords: Quality of life, health service perception, satisfaction

Yazışma Adresi: Aylin SARI Department of Physical Therapy And Rehabilitation, Istanbul Erenkoy Physical Therapy and Rehabilitation Hospital, Istanbul, Turkiye Phone: 05058396368 e-mail:mdaylinsari@gmail.com

ORCID No (Sirasiyla): 0000-0002-0391-2940, 0000-0001-8818-1050, 0000-0001-9179-0551, 0000-0002-9586-9547 


\section{INTRODUCTION}

Health services are the activities carried out to ensure that the individual, and society are healthy, long-lasting, and work efficiently. The provision of health services covers all the studies for health protection, treatment, and rehabilitation of diseases (1).

The content, structure, processes, and results of health services in general, and especially hospital services are different from other service sectors. This difference stems from the direct relationship of the health system with human health. The prevalence, continuity, and availability of health services are no longer sufficient; how satisfied people are with the services that are widespread, continuous, and accessible have become important $(1,2)$.

Quality of life is the term that refers to the general level of welfare and access to individuals or communities. It can be explained as the perception of the individual situation in life in terms of the system to cultural values and expectations. It defines the difference between the individual's expectations and experiences (3).

The way health perceptions are based on people's self-assessment of their health status, in general, is a simple yet powerful indicator that reflects the multidimensionality of health and allows the individual to assess his or her biological, mental, and social situation. Socio-demographic characteristics and quality of life can affect perception and patient satisfaction of developing and changing health services. The availability and thorough examination of these effects should be updated within the scope of today's health care services (1-3).

Determining the level and how socio-demographic factors and quality of life affect the health service perception is vital in increasing quality and efficiency in healthcare service delivery. Accordingly, this study was planned to investigate the effect of the sociodemographic characteristics and quality of life of the patients who applied to the outpatient clinic in Erenköy Physical Therapy and Rehabilitation Hospital on the perception of health care.

\section{MATERIALS AND METHODS}

This cross-sectional study was conducted on a total of 367 patients (236 female, 131 male) who met the criteria for participation in the research and applied to the outpatient clinic of a Physical Therapy and Rehabilitation Hospital between June 15-September 15, 2019.

The inclusion criteria were, being older than 18 years, patients with a minimum of 24 mini-mental scores. Exclusion criteria were; the presence of sensory problems such as vision, hearing, presence of disease that could interfere with communication, and being younger than 18 years.

Written permission and approval from the local ethics committee were obtained from the relevant institution before starting the study.
The patients were informed about the research to be performed, and it was stated that the confidentiality of the information they would give would not be used, and they would not be used for any purpose other than the research. Data were collected by face-to-face interviews with those who agreed to participate and signed the informed consent form.

Data were collected using a structured form that measures the socio-demographic characteristics and satisfaction levels of the patients. We prepared a structured questionnaire by the literature. The questionnaire consisted of two parts. The first part includes socio-demographic data consisting of 9 items as age, gender, marital status, economic status, education level, relationship with the environment, presence of health assurance, previous admission to hospital, and referral to the hospital; second part includes patient satisfaction level consisting of 23 items. The Nottingham Health Profile Scale was used to measure the general perceived quality of life of the patients. NHP is a general quality of life questionnaire that assesses the perceived health problems of the individual and how these problems affect their daily activities. The NHP was developed in the United Kingdom and translated into many languages. Küçükdeveci et al. prepared the Turkish version., and its validity and reliability were made (1-3).

\section{STATISTICAL ANALYSIS}

In this study, statistical analysis was done with the NCSS (Number Cruncher Statistical System) 2007 Statistical Software (Utah, USA) package program. In addition to the descriptive statistical methods (mean, standard deviation), the distribution of variables was examined with the Kolmogorov Smirnov normality test, and the input of the variables with normal distribution was evaluated. The t-test and Pearson chi-square test were for group comparisons, Mann Whitney $\mathrm{U}$ test for intergroup comparisons, and at the end, multiple linear regression analysis were examined. The results were evaluated at the significance level of $\mathrm{p}<0.05$.

\section{RESULTS}

Descriptive characteristics of the cases included in the study are given in Table 1. The distribution of the relationship between NHP scores according to the satisfaction levels of the patients with the hospital service departments is given in Table 2. A statistically significant correlation was observed between NHP Pain and the average scores of the Physical Examination, Laboratory Department, Radiology Department, General Satisfaction, Total Satisfaction ( $\mathrm{p}=0.002$, $\mathrm{p}$ $=0.0001, \mathrm{p}=0.006, \mathrm{p}=0.001, \mathrm{p}=0.001$, respectively). There was a statistically significant negative correlation between NSP Emotional Reaction mean scores with Patient Admission Satisfaction scores $(\mathrm{p}=0.049)$.

There was a statistically significant negative correlation between NSP Social Isolation mean scores with the Radiology Department's Satisfaction mean scores $(p=0.006)$. 
There was no statistically significant difference between NSP Sleep, Physical Activity, Energy, and Part 2 scores and Satisfaction average scores ( $\mathrm{p}>0.05)$.

The distribution of the relationship between patient age according to the satisfaction levels of the patients with the hospital service departments is given in Table 3. The distribution of the relationship between educational levels according to the satisfaction levels of the patients with the hospital service departments are shown in Table 4. When the distribution of the scores obtained from the hospital service departments of the cases by gender is examined, there was no statistically significant difference between the total satisfaction scores of male and female patients ( $p>0.05)$.

When the distribution of scores obtained from hospital service departments according to marital status, there was no statistically significant difference between the total satisfaction scores of married, single, widowed, and divorced, marital status groups ( $\mathrm{p}>0.05)$.

When the distribution of the scores obtained from hospital service departments according to income level, there was no statistically significant difference between the total satisfaction scores of the low, middle, and high-income groups ( $\mathrm{p}>0.05)$.

When the distribution of the scores obtained from the hospital service departments of the patients according to health assurance, there was no statistically significant difference between the total satisfaction scores of the Health Assurance $(+)$ and Health Assurance (-) groups ( $\mathrm{p}>0.05)$.

When the distribution of the scores obtained from the hospital service departments of the patients according to the close environment (relatives and neighbors) relationship, there was no statistically significant difference between the total satisfaction scores of good, very good, and excellent relationship groups $(\mathrm{p}=0.05)$.

When the distribution of the scores obtained from the hospital service departments of the patients with the status of coming to the hospital, there was no statistically significant difference between total satisfaction mean scores of first-time and two or more hospital coming groups ( $\mathrm{p}>0.05$ ).

When the distribution of the scores obtained from patients according to the hospital recommend status, the total satisfaction average scores of the Recommend Hospital (+) group were found to be significantly higher than the Recommend Hospital (-) group ( $\mathrm{p}=0.0001)$.
Table 1. Distribution of the descriptive characteristics of the cases

\begin{tabular}{|c|c|c|c|}
\hline & & $\mathbf{N}$ & $\%$ \\
\hline \multirow[t]{2}{*}{ Gender } & Female & 236 & 64.31 \\
\hline & Male & 131 & 35.69 \\
\hline \multirow[t]{4}{*}{ Martial status } & Married & 262 & 71.39 \\
\hline & Single & 67 & 18.26 \\
\hline & Widow & 26 & 7.08 \\
\hline & Divorced & 12 & 3.27 \\
\hline \multirow[t]{4}{*}{ Educational status } & Literate & 54 & 14.71 \\
\hline & Primary School & 135 & 36.78 \\
\hline & High School & 113 & 30.79 \\
\hline & University & 65 & 17.71 \\
\hline \multirow[t]{2}{*}{ Health assurance } & Yes & 315 & 85.83 \\
\hline & No & 52 & 14.17 \\
\hline \multirow[t]{3}{*}{ Income status } & Low & 170 & 46.32 \\
\hline & Middle & 165 & 44.96 \\
\hline & High & 32 & 8.72 \\
\hline \multirow{3}{*}{$\begin{array}{l}\text { Relationship } \\
\text { (relatives and } \\
\text { neighbors) }\end{array}$} & Good & 67 & 18.26 \\
\hline & Very good & 210 & 57.22 \\
\hline & Excellent & 90 & 24.52 \\
\hline \multirow[t]{2}{*}{ Arrival status } & First & 169 & 46.05 \\
\hline & Two or more & 198 & 53.95 \\
\hline \multirow{2}{*}{$\begin{array}{l}\text { Reapplying to the } \\
\text { hospital } \\
\text { or Recommend to } \\
\text { Others }\end{array}$} & Yes & 320 & 87.19 \\
\hline & No & 47 & 12.81 \\
\hline
\end{tabular}


Table 2. Distribution of the relationship between the NHP scores according to the satisfaction levels of the hospital service departments

\begin{tabular}{|c|c|c|c|c|c|c|c|c|}
\hline \multicolumn{9}{|c|}{ NHP } \\
\hline & & Pain & $\begin{array}{l}\text { Emotional } \\
\text { Reactions }\end{array}$ & Sleep & $\begin{array}{l}\text { Social } \\
\text { Isolation }\end{array}$ & $\begin{array}{l}\text { Physical } \\
\text { Activity }\end{array}$ & Energy & Part 2 \\
\hline \multirow[t]{2}{*}{ Admission } & $\mathrm{r}$ & 0.101 & -0.103 & -0.088 & -0.082 & 0.011 & -0.001 & -0.042 \\
\hline & $\mathrm{p}$ & 0.053 & 0.049 & 0.094 & 0.118 & 0.829 & 0.987 & 0.423 \\
\hline \multirow[t]{2}{*}{ Physical Examiantion } & $\mathrm{r}$ & 0.158 & -0.032 & -0.03 & -0.035 & 0.07 & -0.006 & -0.007 \\
\hline & $\mathrm{p}$ & 0.002 & 0.538 & 0.566 & 0.510 & 0.184 & 0.914 & 0.891 \\
\hline \multirow[t]{2}{*}{ Laboratory } & $\mathrm{r}$ & 0.189 & -0.044 & 0.003 & -0.063 & 0.083 & 0.056 & -0.012 \\
\hline & $\mathrm{p}$ & 0.0001 & 0.400 & 0.955 & 0.227 & 0.091 & 0.286 & 0.815 \\
\hline \multirow[t]{2}{*}{ Radiology } & $\mathrm{r}$ & 0.144 & -0.086 & -0.031 & -0.142 & 0.066 & 0.038 & -0.037 \\
\hline & $\mathrm{p}$ & 0.006 & 0.092 & 0.559 & 0.006 & 0.209 & 0.466 & 0.474 \\
\hline \multirow[t]{2}{*}{ General Satisfaction } & $\mathrm{r}$ & 0.175 & -0.054 & -0.018 & -0.098 & 0.096 & 0.048 & 0.009 \\
\hline & $\mathrm{p}$ & 0.001 & 0.301 & 0.736 & 0.061 & 0.068 & 0.358 & 0.866 \\
\hline \multirow[t]{2}{*}{ Total Satisfaction } & $\mathrm{r}$ & 0.176 & -0.076 & -0.036 & -0.095 & 0.082 & 0.031 & -0.02 \\
\hline & $\mathrm{p}$ & 0.001 & 0.146 & 0.490 & 0.07 & 0.117 & 0.553 & 0.706 \\
\hline
\end{tabular}

Pearson Correlation test

Table 3. Distribution of the relationship between patient age according to the satisfaction levels of the patients with hospital service departments

\begin{tabular}{|l|c|c|}
\hline \multirow{2}{*}{ Admission } & & Age \\
\hline Physical Examination & $\mathrm{r}$ & 0.173 \\
\hline Laboratory & $\mathrm{p}$ & 0.001 \\
\cline { 2 - 3 } & $\mathrm{r}$ & 0.149 \\
\hline Radiology & $\mathrm{p}$ & 0.004 \\
\hline & $\mathrm{r}$ & 0.173 \\
\hline General Satisfaction & $\mathrm{p}$ & 0.001 \\
\hline Total Satisfaction & $\mathrm{r}$ & 0.221 \\
\hline & $\mathrm{p}$ & 0.0001 \\
\hline & $\mathrm{r}$ & 0.229 \\
\hline
\end{tabular}

Pearson Correlation test 
Table 4.Distribution of the relationship between educational levels according to the satisfaction levels of the patients with hospital service departments

\begin{tabular}{|c|c|c|c|c|c|}
\hline * & $\begin{array}{l}\text { Literate } \\
\mathrm{N}: 54\end{array}$ & $\begin{array}{c}\text { Primary School } \\
\text { N:135 }\end{array}$ & $\begin{array}{l}\text { High School } \\
\text { N:113 }\end{array}$ & $\begin{array}{c}\text { University } \\
\text { N:65 }\end{array}$ & $\mathbf{p}$ \\
\hline Admission & $82.87 \pm 15.81$ & $76.54 \pm 20.34$ & $77.14 \pm 19.18$ & $75.64 \pm 19.73$ & 0.162 \\
\hline Physical Examiantion & $82.92 \pm 18.40$ & $76.22 \pm 21.30$ & $75.71 \pm 21.29$ & $70.09 \pm 23.32$ & 0.014 \\
\hline Laboratory & $81.33 \pm 18.80$ & $75.06 \pm 20.30$ & $73.38 \pm 20.71$ & $67.56 \pm 22.45$ & 0.004 \\
\hline Radiology & $82.41 \pm 16.56$ & $74.32 \pm 19.90$ & $71.31 \pm 21.48$ & $69.87 \pm 19.53$ & 0.003 \\
\hline General Satisfaction & $75.54 \pm 22.03$ & $72.87 \pm 20.88$ & $66.85 \pm 20.34$ & $66.80 \pm 20.73$ & 0.017 \\
\hline Total Satisfaction & $81.01 \pm 15.97$ & $75.00 \pm 18.64$ & $72.88 \pm 17.55$ & $69.99 \pm 18.31$ & 0.007 \\
\hline ** & $\begin{array}{c}\text { Physical } \\
\text { Examiantion }\end{array}$ & Laboratory & Radiology & $\begin{array}{c}\text { General } \\
\text { Satisfaction }\end{array}$ & $\begin{array}{c}\text { Total } \\
\text { Satisfaciton }\end{array}$ \\
\hline Literate/Primary School & 0.206 & 0.235 & 0.058 & 0.857 & 0.159 \\
\hline Literate/ High School & 0.172 & 0.093 & 0.005 & 0.048 & 0.032 \\
\hline Literate/ University & 0.006 & 0.002 & 0.004 & 0.045 & 0.005 \\
\hline $\begin{array}{l}\text { Primary School / High } \\
\text { School }\end{array}$ & 0.998 & 0.919 & 0.636 & 0.109 & 0.788 \\
\hline Primary School/University & 0.226 & 0.077 & 0.450 & 0.218 & 0.249 \\
\hline High School/University & 0.325 & 0.269 & 0.967 & 0.999 & 0.728 \\
\hline
\end{tabular}

*One Way Analysis of Variance ** Tukey Multiple Comparison Test

\section{DISCUSSION}

Constantly changing technology, factors such as information, increased costs, increased patient complaints, reasonable care requests, cause health services to become more complex. Assessing health service perception and satisfaction is an essential parameter in understanding the needs of the patient and improving the quality of services (4). This study aimed to determine the effect of quality of life and socio-demographic characteristics on the perception of health care of patients admitted to the outpatient clinic.

As the age of the sociodemographic characteristics examined in our study, the satisfaction levels of the patients regarding hospital service departments increases with increasing age. Different studies have shown that general satisfaction and life satisfaction increase with age (5-10). In terms of education levels, total satisfaction level was found to be high in all education levels, but satisfaction was higher in those with low education levels. Carr-Hill also reported that patients with higher levels of education might be less satisfied that they expect a higher standard (11). Studies are supporting our results and showing that satisfaction decreases with increasing education level. The higher the education level, the more conscious the patient, the more his expectations and wishes; as a result, satisfaction is lower $(5,12)$.

Studies are showing different relationships between marital status and gender, and satisfaction, but no relationship was found in our study $(5,14)$. Daig et al. showed that older men and women have differences in life satisfaction (15). In their study, Quintana et al. found a significant relationship with patient satisfaction and age, gender, and educational status (5). It is seen that those who would prefer the hospital to be served again and recommend it to others in the study have high satisfaction levels (13). They found that social adjustment and satisfaction may be higher in individuals who are good in close relationships and that close relationships lead to high life satisfaction. In our study, no relationship was observed between satisfaction and close relationships (16). This finding may be explained by the fact that the patients may not have given the typical response because of self-evaluation. NHP is a quality of life scale that examines a person's perceived health status in terms of social, physical, and emotional aspects. It consists of two parts. Chapter 2 examines more specific areas, such as paid work, domestic affairs, social life, life at home, sexual life, hobbies, and interests (3). In our study, the satisfaction level of patients with pain in the first part of NHP was found to be high at all stages. The main reason for this may be the belief that pain patients will be treated after admission. Also, it contributes to this satisfaction in the attitudes and behaviors it encounters with a sense of trust in the place it applies (17). The satisfaction rate was found to be low in patients with high emotional regression. The instant emotional reaction at the time of admission led to low satisfaction in the patient. This emotional activity can be anxiety, fear, impatience, nervousness, and so on. Such a relationship was not observed in the overall and total satisfaction levels with all stages of the examination. The relationship between initial emotional reaction and low satisfaction 
disappears along with the belief that treatment will be treated and a sense of confidence (9).

The study was cross-sectional, and many variables, such as the patient group, region, institution, and employees involved in the study, may affect results. Also, the fact that we created a structured questionnaire that determines the perception of health service is another limitation of our study.

As a conclusion, in general, the satisfaction of the participants in this study due to the perception of health service was related to age, education level, and pain from the quality life parameters. However, any problems that may occur in patient-hospital communication will affect satisfaction and health service perception. To prevent these problems, it is necessary to follow this communication with more detailed, wide-ranging studies carefully.

\section{Compliance with ethical standards}

\section{Funding}

The authors received no financial support forthe research, authorship and/or publication of this article.

\section{Conflict of interests}

The authors have no conflict of interests to declare.

\section{REFERENCES}

1. World Health Organization. Health Education and Health Promotion Unit. (2003). Health and development through physical activity and sport. Geneva:World Health Organization. http:// www.who.int/iris/handle/10665/67796

2. Press I, Patient Satisfaction: Defining, Measuring, And Improving The Experience Of Care. Chicago: Health Administration Pres. 2002:88.

3. Kücükdevecı A, Mckenna S, Kutlay S, Gürsel Y, Whalley D, Arasil, T. The Development And Psychometric Assessment Of The Turkish Version Of The Nottingham Health Profile. Int J Rehabil Res. 2000;23(1):31-38.

4. Núñez E, de Adana Ruiz R. Incorporate hemodialysis pa-tient's satisfaction to quality management. J Health cQual Res. 2019;34(5):266-271.

5. Quintana J, González N, Bilbao A, Aizpuru F, Escobar A, Esteban C. et al. Predictors of Patient Satisfaction with Hospital Health Care. BMC Health Serv Res. 2006;6:102.

6. RodgersVivien, NevilleStephen, La Grow Steven. Health, functionalabilityand life satisfactionamongolderpeople 65 yearsandover: a cross-sectional study. Contemp Nurse. 2017;53(3):284292.

7. Hargraves JL, Wilson IB, Zaslavsky A, James C, Walker JD, Rogers G, Cleary PD: Adjusting for patient characteristics when analyzing reports from patients about hospital care. Med Care. 2001;39:635-641.

8. Jaipaul CK, Rosenthal GE: Are older patients more satisfied with hospital care than younger patients? J Gen Intern Med. 2003;18:23-30.
9. Elagi A AA, Jaber B A, Wassly A H A, Ahmed R M S, Bosily F AA. Public's perception and satisfaction on the role and services provided by family physicians in SaudiArabia: A cross-sectional study. J Family Med Prim Care. 2019;8(10):3282.

10. Demirci A, Öztürk Z, Hatipoğlu S. Bakırköy Dr. Sadi Konuk Eğitim Araştırma Hastanesi'nde Hasta Memnuniyeti ve Etkileyen Faktörlerin Araştırılması. Med J Bakirkoy. 2018;14(1).

11. Carr-Hill, Roy A. Themeasurement of patientsatisfaction. Journal of publichealth. J Public Health (Oxf). 1992;14(3):236-249.

12. Crow R, Gage H, Hampson S, Hart J, Kimber A, Storey L, Thomas $\mathrm{H}$ : The measurement of satisfaction with healthcare: implications for practice from a systematic review of the literature. Health Technol Assess. 2002;6:1-244.

13. John J: Patient satisfaction: the impact of past experience. J Health Care Mark. 1992;12:56-64.

14. Hall JA, Dornan MC: Patient sociodemographic characteristics as predictors of satisfaction with medical care: a meta-analysis. Soc Sci Med. 1990;30:811-818.

15. Daig I, Herschbach P, Lehmann A, Knoll N, Decker O. Gender and age differences in domain-specific life satisfaction and the impact of depressive and anxiety symptoms: a general population surveyfrom Germany. Qual Life Res 2009;18:669-678.

16. Oishi S, Diener E, Lucas RE. The optimum level of well-being: Can people be too happy? Perspect Psychol Sci. 2007;2:346-360.

17. Baker R, Mainouslii A G, Gray D P, Love M M. Exploration of the relationship between continuity, trust in regular doctors and patient satisfaction with consultations with family doctors. Scand J Prim Health Care. 2003;21(1):27-32. 